\title{
シンポジウム（2） 食道動態とその臨床
}

\section{$\mathrm{X}$ 線による食道動態の観察とその臨床的意義}

\section{はじめに}

食道の疾患においては病変が高度になるか他 の原因による病変が加わらないと, 食道の疾患 らしい訴えとして診を求めないことが多い。従 つて食道疾患の早期診断は不定愁訴の時期にお いて詳細な検索を行らことによつてのみ可能と なる。今回シンポジウムとして取り上げられた 食道動態の問題は一つにはそうした目的をもつ ているし，他方には食道の動態は余り追及され ていないので不明な点が少くなく, 特にその臨 床的意義は明確にされていない。ここにおいて 食道の動態をX線的に観察するのはどの様な臨 床的意義を有するかについて検討するために， X線映画，連続撮影などによる成績を基として 本検索を行つた。

\section{X線による観察}

正常人の讌下の状態をX線映画で観察すると 正面においても側面においても，スムースに矒 下されて殆んど停滞がなく, 僅かに梨子状窩, 喉頭蓋谷に停滞あるものも次の 1,2 回の空嚥 で消失する。そしてそれ以下の食道通過はスー ッと進んで噴門部では再び胃におし入れる様な 運動が見られる。これに対し頸部食道癌の患者 における嚥下の状態を見ると, 頸部に停滞して いることが著明であり，何回も曣下をくり返し て少しづつ送り込んでいることがよく認められ る。正面からこの状態を見ると停滞している状 が左右不整であり, 特に停滞の著しい部に掠い てはその部の運動が不良であることが認めら れ，その直上部では運動極めて活発であり，少 し宛蟮下されているが，一側に偏している。従 つて側方からの観察では停滞と気の毒なほど繰 り返す無下運動を認めるに過ぎない。しかして 頸部を通過するとその後は正常の場合と全く同 様にスムースに通過するのを認める。

\footnotetext{
* 名古屋大学医学部耳鼻咽喉科学教室 教授
}

* 後 藤 修 二

この正常食道の動態と頸部食道癌とを比較す ると著明な差異が認められる。しかし臨床的な 立場から見るとこの映画観察によつてどの程度 に意義が大きいかどらかが重要な点である。

そこで第 1 図，第 2 図のX線を見ると，これ だけで, 前者は胸部食道癌が疑わしいし, 後者 では頸部食道癌が疑われる像である。また第 3 四では食道拡張症，第 4 図では食道秝室という 診断がつけられる。従つて臨床的に病名をつけ るという診断だけならば第 1 図一 4 図の様な $\mathrm{X}$ 線撮影で充分ではないかということになる。し かしこの様なX線像では食道筋層の変化である とか, 内部変化の詳細, 周囲との関係などを知 ろらとすれば動的に観察しなければならない。

ここにおいてX線映画によつて食道㗭室の動 態を観察するに，頽室は食道蠕動と共に縮少或 は消失に近くなるが，蠕動波が過ぎて弛緩にな

第 1 図

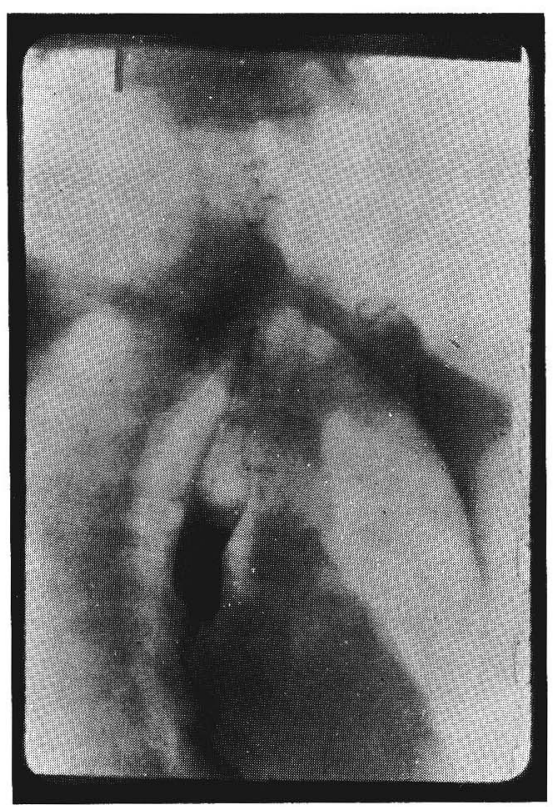


第 2 図

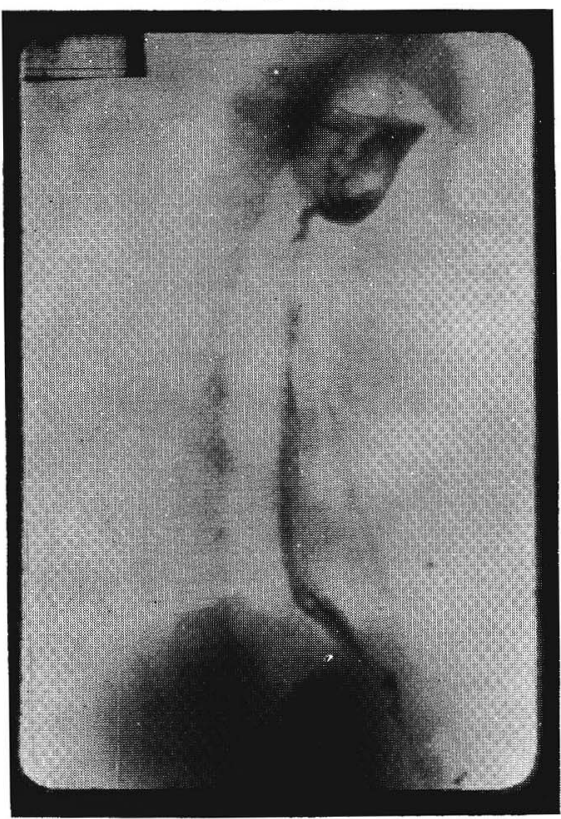

第 3 図

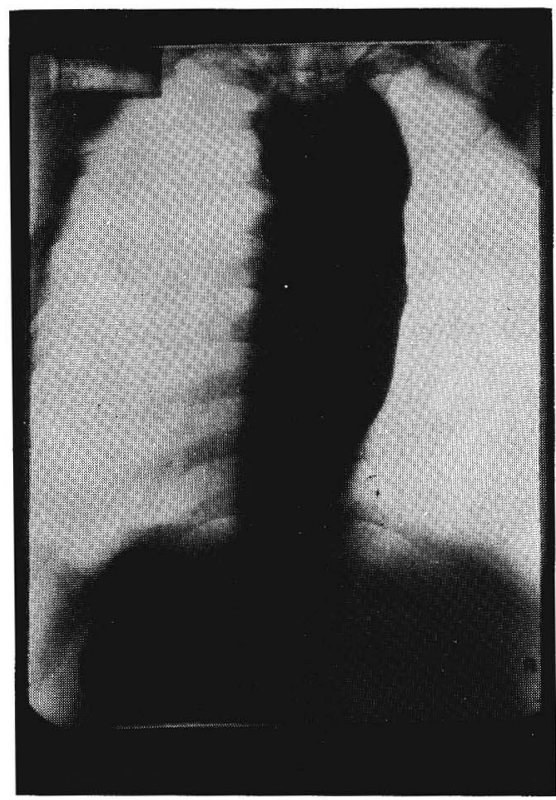

ると䄭室は著明に認められる。しかして食道の 運動と共に或は䄸室内に造影剤が入つて停滞し ていたり，或は送り出されたりしている。票室 はその発生部位によつてどの方向から観察する かによつて見易かつたり，見逃され易い。従つ
第 4 図

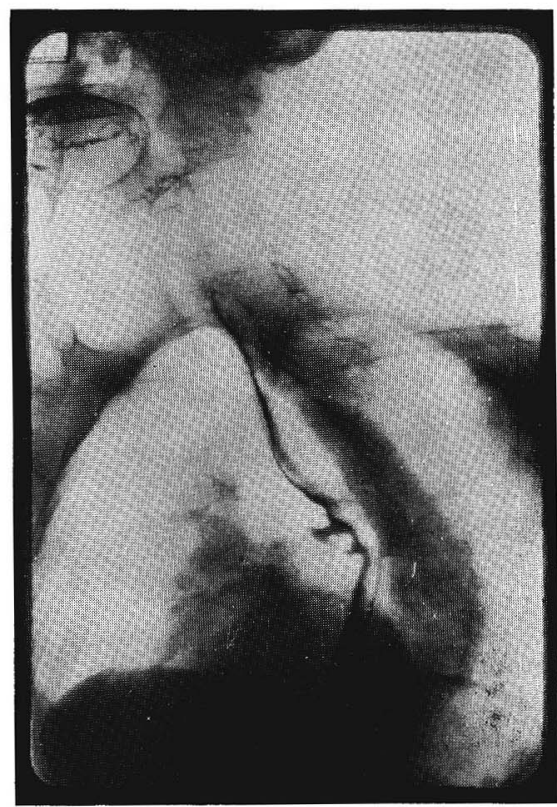

の方向から検索しなければならないのは然で ある。映画による食道䕀室の観察はその動態を 見るには以上の様に非常に適当しているが, 他 方鄎室内部の変化を詳しく見ようとすると必ず しも適当していない。

次に食道拡張症のX線映画を見ますと，曣下 に当つては正常と全く同じく, どんどん入つて 行きます。ところが下部食道にどんどん溜つて いて食道は強く拡張しています。そして少し宛 胃に送り込まれています。食道に蠕動波は明か ですが，逆蠕動の様なのも認められ，何れにし ても下部食道は拡張し,ここに停滞してい名。 この場合においても拡張食道の内部方状態はど うなつているのかよくは解らない。従つて映画 によつては食道の動態が拡張症ではどの様に異 つているかを大まかに知るには適しているが， 細かい動態の異常及び内部の詳細な変化を知る には映画による観察は適当していない。

ここにおいて第 5 図，第 6 図に示すように食 道秝室, 食道拡張症のX線像を見る。これによ ると映画の場合と異つて㮩室では内部にもやも やした陰影のあることが認められて炎症の存在 が疑われる。又食道拡張でも造影剤の少い部位 て㮩室を有する食道の動的観察においても色々においては権譬が屈曲したり, 斜走したりして 
第 5 図

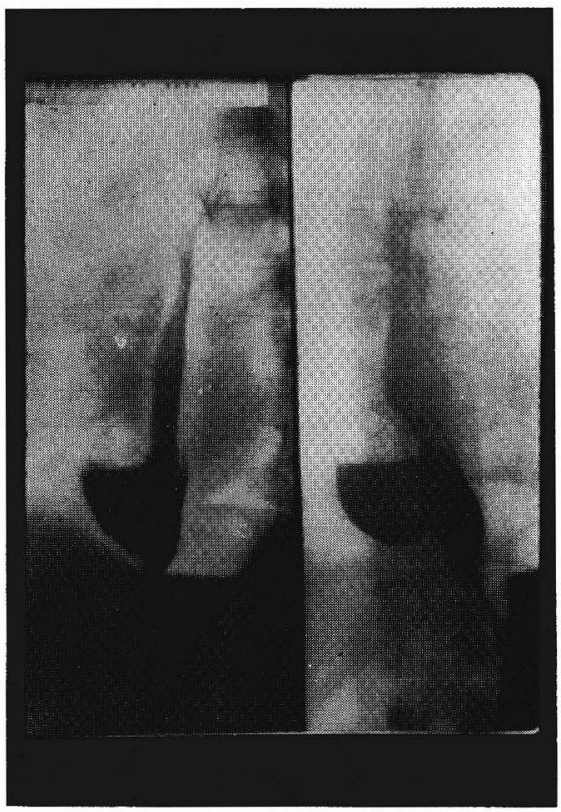

第 6 図

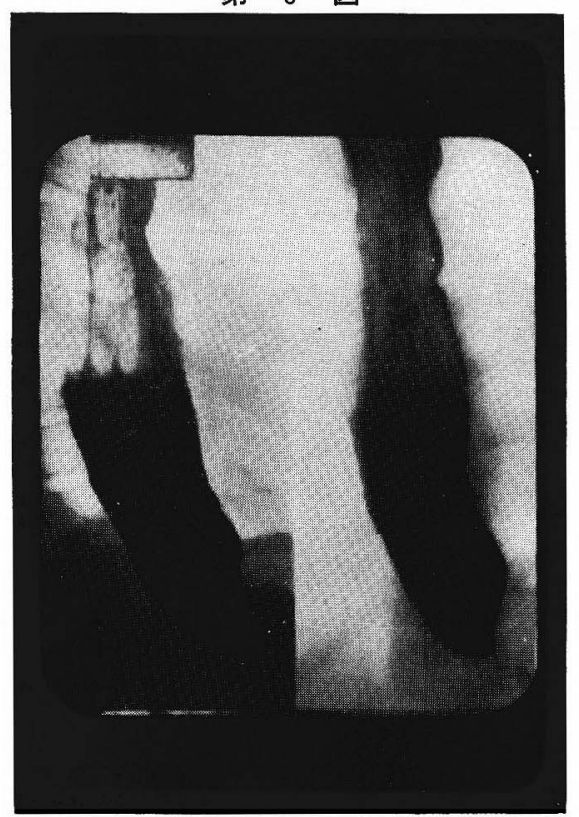

いるのが認められるし，充盈した部位において は攣縮が認められる。即ちこれらX線像の方が 映画で観察する場合よりは細部については判読 し易い。と云つても食道の充盈像のみでは不充 分であり，Relief 像も必要である。この様に考 えると映画の意義がない様に思われるが，動態
の観察には絶対に必要である。即ち上記の㮩 室，拡張症などにおける機能的の変化，あるい は炎症性変化の合併又はその鑑別, さらに周囲 との関係などを知ろうとすれば，X線的にも食 道の動態の観察が重要であり，そのためにX線 透視, 映画, テレビ, 連続撮影などが必要にな る。例えば第 7 図に示す様な像においては，こ

第 7 図

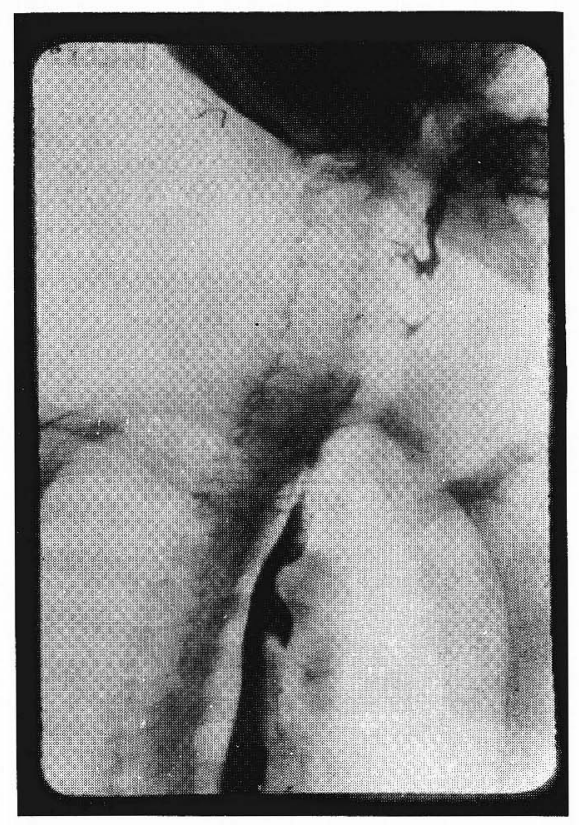

の突出した様に見える食道の部は㕷室であるの か，逆に食道が大動脈及び気管支によつて圧迫 され，その間の大動脈気管支間三角が著明に認 められているに過ぎないのか直ちに断言し得ら れない。さらに第 8 図に示す様に造影剤が停滞 しているのは食道に病変あるためによるのか, 頸推の変化などによる 2 次的のものであるか は, この像からだけでは解らない。即ちX線上 に食道の変化として認められるものは, 食道そ のものの病変によつて出現した像である他に, 食道周囲器官の腫大, 走行異常, 炎性変化など による食道の contour, 走行, 大さ, 運動など の変化が出現することのあるのは当然であり, さらに胃，十二指腸などの病変の存在する場合 に反射性に食道に㾔卛様の変化の起ることのあ ることも充分理解していなければならない。こ こに食道動態の観察の必要が臨床的に強調され 


\section{第 8 図}

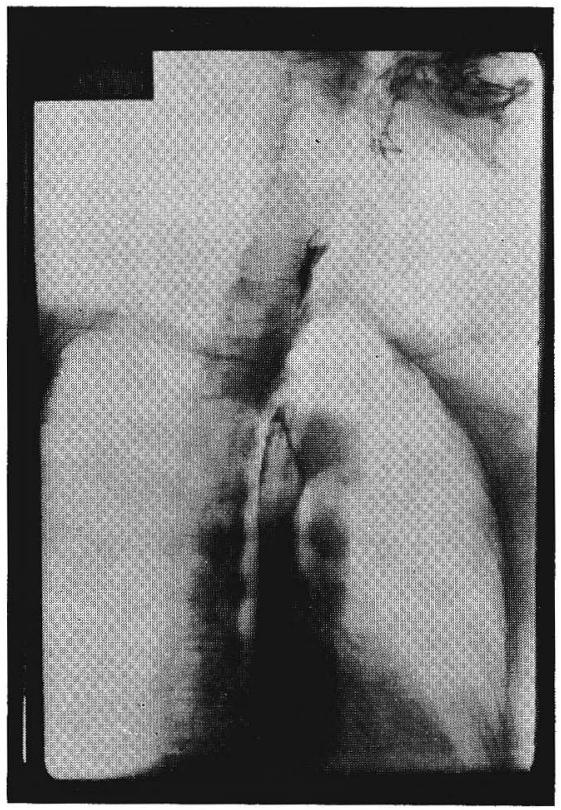

るのである。

食道のX線像の観察に打いて充盈像と Relief 像において異つた所見を認めることについては すでに述べた。ここにこの問題について再び述 べて見る。即ち食道病変としては上述のものと 異つた疾患について述べょうとするのである。

第 9 図

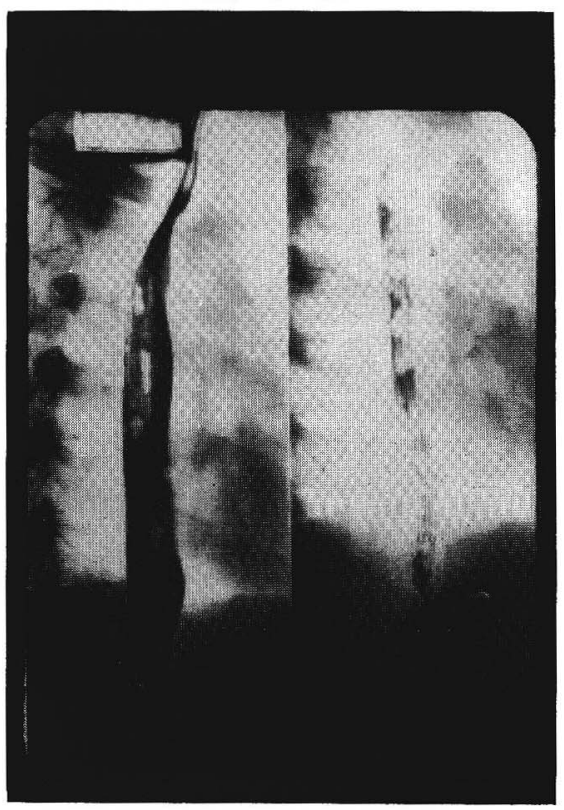

第 10 図

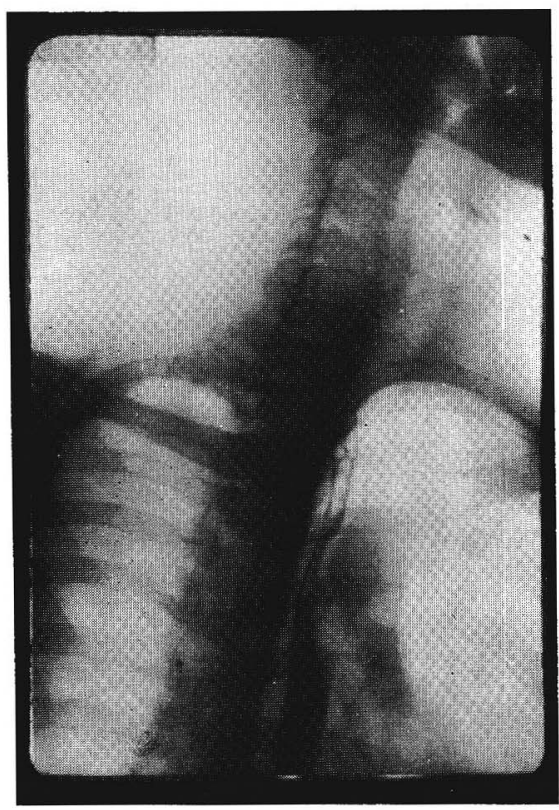

第 9 図左に示す様に filling phase で陰影欠損あ るいは鋸歯状を呈しており，これが第 9 図右及 び第10図上部の様に Rest phase では蛇皮状, 石襝泡状, 虫に喰われた葉の状であるものがあ る。この例は食道静脈瘤である。食道静脈瘤を X線的に診断するには後者の様な Rest phase における特異な所見によるのであるが，この像 は時期によつて異るので連続した撮影が望まし 、。第11図に示す様に filling phase で食道輪廓 が不規則であり，しかも狭窄した様な状態であ るが， Rest phase では第12図に示すように粘 膜被譬が巾広かつたり，横貿を形成している。 この例は食道の炎症性変化によるのである。こ の例では Rest phase における Relief の不規則 なことから粘膜の異常が考えられ, filling phase の狭窄状の所見も炎症によるものと考えるので あるが, この断定には勿論直達検查, 試切が必 要である。又第13図に示すように食道壁弛緩状 態のものがあり，反対に食道壁攣縮のものは第 14図に示すようである。この $2 つ の$ 像は現象的 には正反対であるが，その原因は同じで炎症に よるものと考えられる。そのことについては後 述する。

前述のようにX線像に現れた所見が特 異 的 
第 11 図

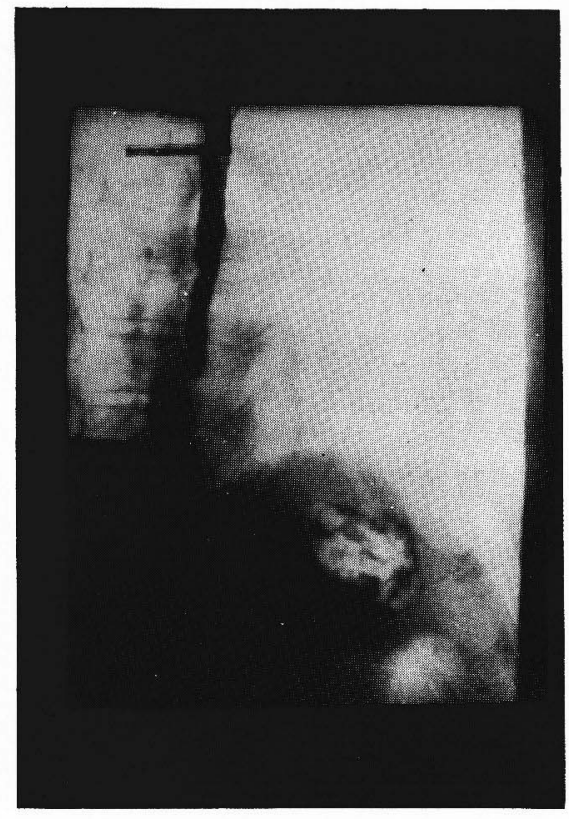

第 12 図

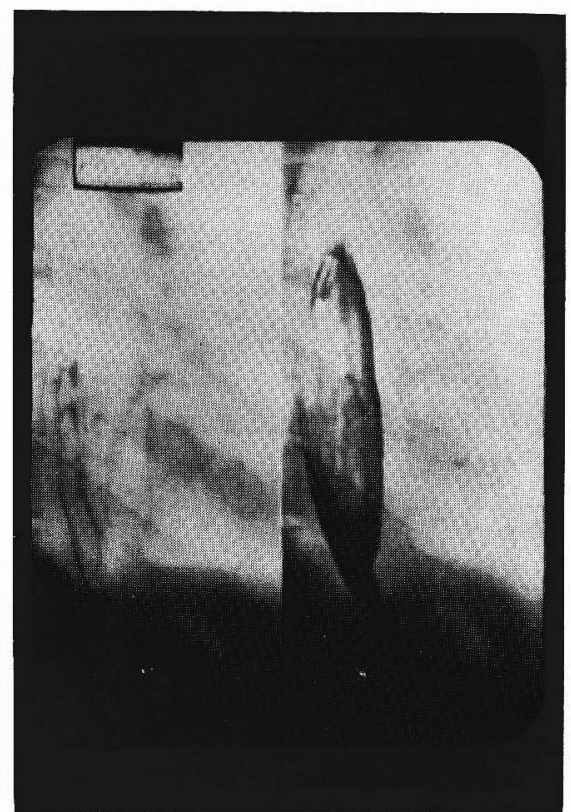

で，一見して診断のつけられるものもあるが, 第15図に示すようにX線像が鞇下，蠕動によつ て異つた所見を呈することが多いし，又第16図 に示すように時期又は体位によつても異つた所 見として認められることが少なくない，さらに X線上に認められる所見が 2 次的の所見のこと
第 13 図

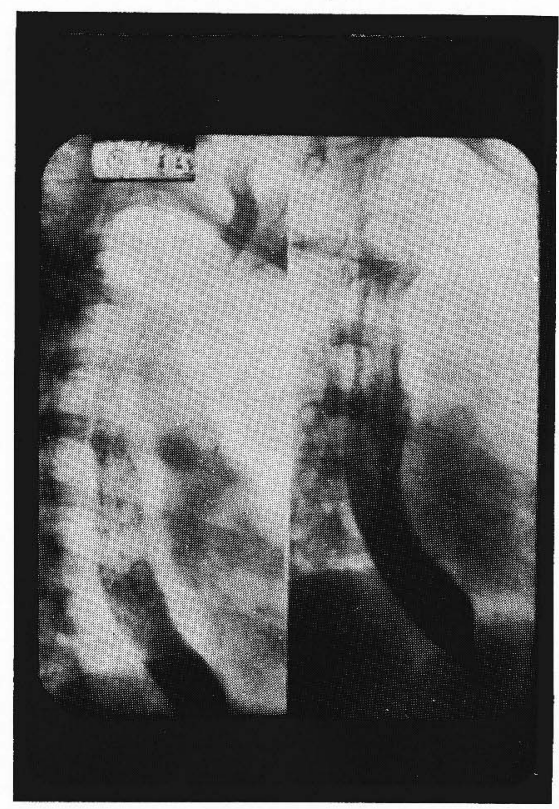

第 14 図

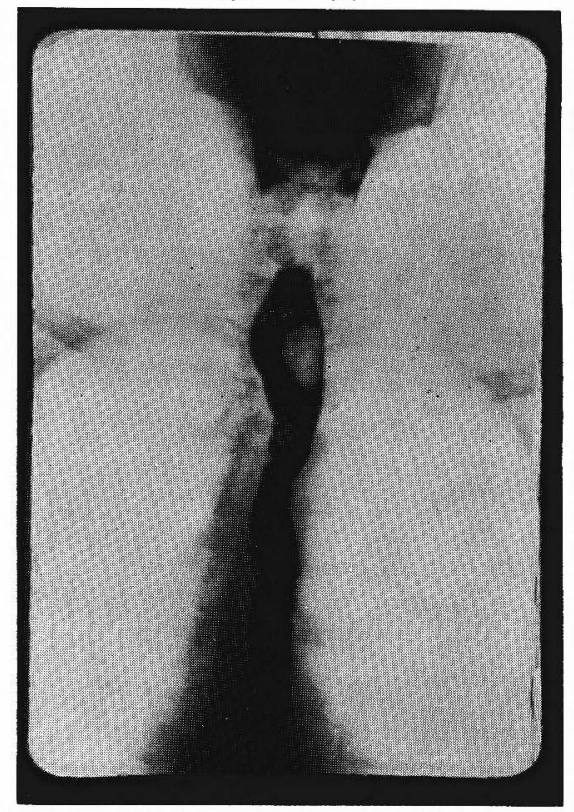

があり，随伴病変による所見のことがあり，特 異所見であるが，他の病変による類似所見であ つたりする。ここにX線像による病変の推定に は食道運動の色々の時期, 種々の方向からの撮 影，色々の体位，さらに薬剂による影響などを 観察しなければならない。ここに食道動態の観 
第 15 図

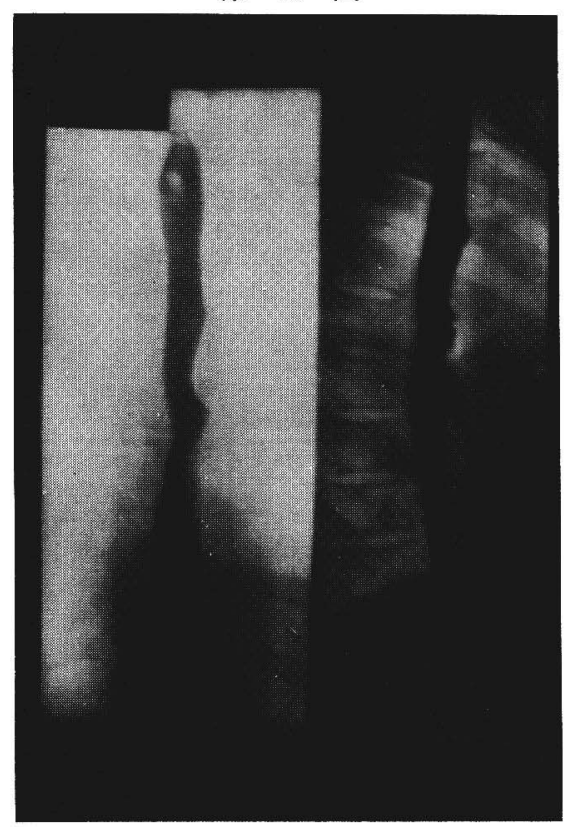

第 16 図

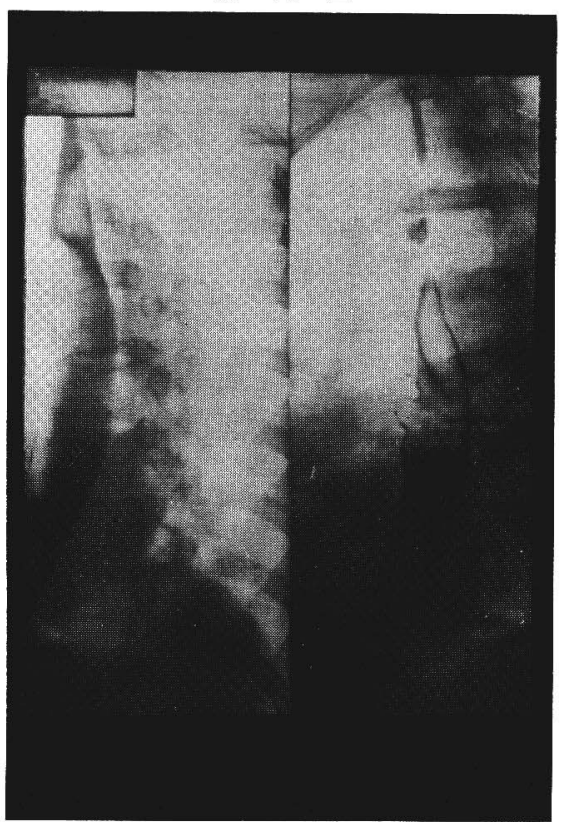

察が重要であり, X線による映画の意義もある。

しかして食道動態の観察を映画によつて行う

と, 食道通過時間の長短を測定することが出来 る。これによつて食道の器質疾患のみでなく, 機能的変化も比較的詳しく知ることが可能であ る。例えば鉄欠乏性食血において食道のX線映
画をとると明かに曣下に時間を要しているが， 特に停滞が甚だしいというのでなく，全体とし て特に燕下の第 2 相に該当するところでスムー スに嚥下されるがおそい。これを映画のコマ数 から時間に計算すると第 1 表のようである。

第1表 Kelly-Paterson症候群における煩咽頭藇 下期

$\begin{array}{ll}\text { 正 常 } & 0.9 \sim 1.1 \text { 秒 } \\ \text { 血清鉄低下者 } & 2.0 \sim 3.8 \text { 秒 } \\ \text { 鉄剂投与後 } & 0.9 \sim 1.3 \text { 秒 }\end{array}$

即ち血清鉄低下の Kelly-Paterson症候群のも のにおける煩咽頭嚥下に要する時間は正常者と 比較すれば， $2 \sim 3$ 倍以上であり，これに鉄剤 を投与して症状軽快したものでは嚥下時間は殆 んど正常に回復している。この様にX線による 隻道の映画によつて食道通過時間を比較的詳細 に知ることが出来る。

\section{食道動㤠の異常について}

食道の動態には以上の様に色々の障害があ り，異常が認められるのであるが，その障害が どの様な形で出現するかはX線像における所見 が食道の部位によつて異つている。そこでそれ らをまとめて表にすると次のようである。即ち 器下機構に関連する部位では第 2 表に示すよ な所見として出現する。

\section{第 2 表 嬩下機構の異常}

1. Hesitant swallowing

2. Piecemeal swallowing

3. Asymmetrical deglutition

4. Pharyngeal stasis, especially vallecular stasis

5. Aspiration into the trachea

6. Spasmus of pharyngo-esophageal sphincter

7. Pharyngeal laxity

このことについてはX線像あるいは映画所見 から記したところである。即ち輏下に時間がか かり，燕下されるのに少し宛入つて行く。また 正面から観察すれば左右非対称に燕下され，停 滞が明かに認められ，多量停滞のために気管内 流入が少くないし, 食道入口部の痤變, 咽頭弛 緩が認められる。これらの一部は連続撮影又は 映画によらなくても認められるが，これらの色 
気食会報一 18 巻

々の所見を見ようとすれば映画などによらなけ ればならない。

次に胸部食道に認めら机る変化は第 3 表に記 すと掠りである。

\section{第 3 表 胸部食道動態の異常}

1. Secondary contraction

2. Tertiary contraction

3. Tiered spasm

4. Hypotonia and hypokinesis

これらの所見について漌かに記したのみで あるが，レ線写真を観察して認められることも 少くないが，これら変化と佶室との鑑別になる と連続撮影或は映画によらなければならないこ とがあり， tertiary contraction と tiered spasm との区別もそうである。しかしてここに記して おかなければならないのは，かかる名称が今日 統一されていなくて，色々の名称が用いられて いるし，その事は又その意義放いても見解を 異にしていることの証でもある。そこで私の立 場を明かにしておかなければならない。Secondary contraction というのは蠕動波の特殊型で あつて, 通常食道の中 $1 / 3$ 亿起り, 同時に上下に 拡つて行く急速な収縮である。Tertiary contraction 浥々の名称で云われているもので通常 食道の下 $\%$ 又は $3 / 4$ 亿亘る不規則な相接する収縮 であり，同時に起つている様に見える程速かに 続いて起る。そして次波通過後の Senri-evacu ation の状の時に通常起る。そして次の蠕動波 で消失する。Tiere spasm は機能的愁室とも云 われるもので, 多数の䄭室様, 真珠首飾様, キ ルク栓抜き様, バラ状のもの認められる。この 後 2 者の spasmは共存することがあり, Tiered spasmでは㮩室共存することがある。Hypotonia は緊張がなくだらんとした食道で蠕動が認め難 いものであり， hypokinesis も似ているが筋機 能に影響する食道内の変化によるもので両者合 併していることが多い。

第 4 表 Cardia 部動態の異常

1. So-called cardiospasm

2. Intermittent spasm

3. Inadequacy of the cardia
ついで Cardia に認められる変化は第 4 表に 示すよらである。

ここに cardiospasm と記したのは食道抬張症 と云われるもので, 食道の充盈像で容易に認め られることは既に第 3 図，第 6 図に示した通り である。しかし軽症のものでは hypotonia など との区別が難しいことがある。Cadia に間歇的 spasm 起ると食道の挔張が間歇的に起る。これ は通常胃, 十二指腸の潰憶, 胆囊炎, 肝炎々の 他の原因によつて起る。cadia の閉塞不充分と 考えられる所見として胃に入つた造影剂が容易 に食道に逆流する場合で, cardiaの部を食道と 胃は造影剤で連続している。

、以上の様に食道動態に法色々の異常があり, しかもほんの僅かの時間出現する異常なものが あり, 時間と共に変化するものがある。従つて かかる異常を観察するためには映画は極めて便 利である。しかし又映画で核鮮明度が余りょく ないので細部の変化を観察するために連続撮影 も必要である。

ここで食道動態の異常を映画で見るにすでに 記さなかつた中枢神経麻瘦及び筋麻痺を取り上 げる。両者ともに著明な変化が認められ, 器下 機構の異常が先づ目立つて, 容易に苝下され ず，しかも気道内誤嚥も明かに認められる。胸 部食道では hypoton!a, hypokinesis が明かに認 められる。この映画によって食道動態の異常の 多くの所見が認められるが，Tertiary spasmな ぞは認められない，ここに一体Tertiary spasm が出現していないのかどらかは明かでない。こ こにも連続撮影の重要性がある。

\section{$\mathbf{X}$ 線による動態観察の臨床的意義}

X線所見からその病変を判断するに当つて出 来るだけ先づ単純な方法で可能なことが望まし い。そこで第17２0図を示して見る。これらの X線像を観察して臨床的にどの様な病変を推定 するか, 観察する人によつて異ると思う。従つ てこの様なX線像のものを臨床的に病変をきめ るためには, 更に種々の検索を進めなければな らない。そのためにはX線的には動的観察を行 らといらことになる。しかして食道の動的観察 を行うに当つて次の事を常に念頭においていな ければならない。即ち食道は嚥下に関連して上 


\section{第 17 図}

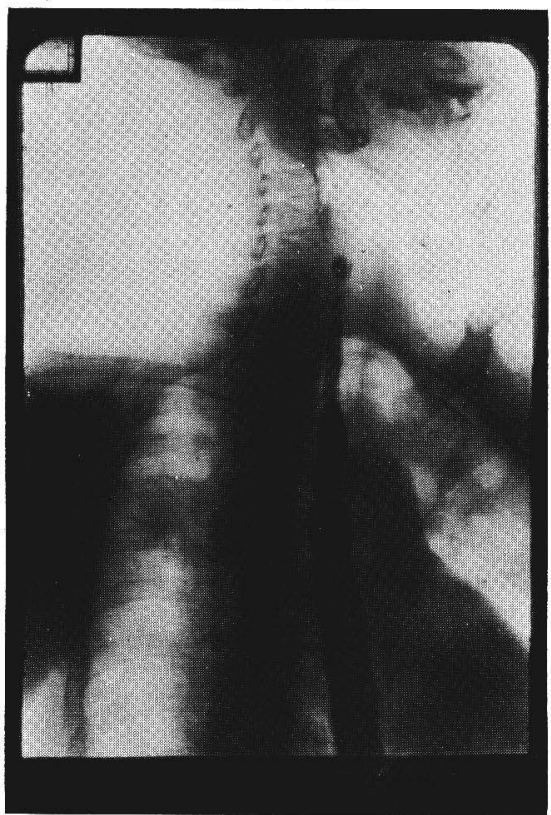

第 18 図

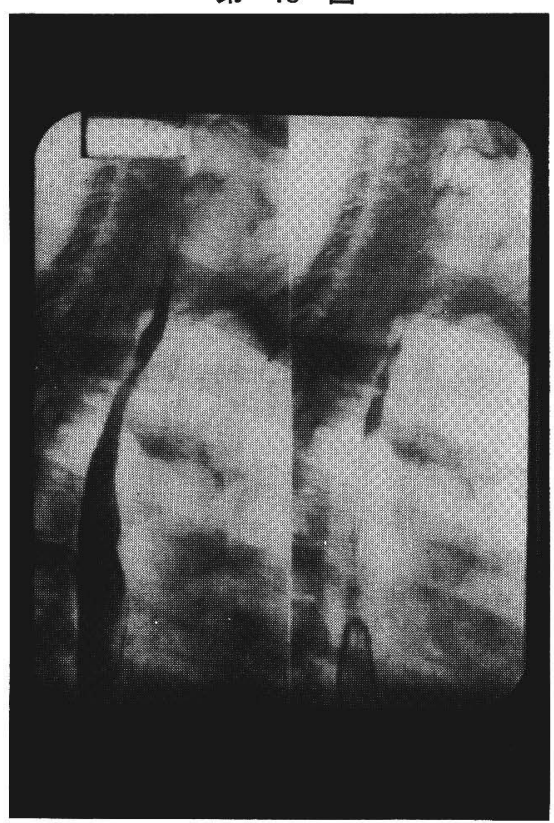

部は損紋筋で構成されているが，下 $\% / 3$ は平滑 筋で構成されており, acting phase と resting phase とをくり返しているといらことであり， これらが食道粘膜の病変, 笳層の変化, 両者の 病変, 或は食道胵の異常のみでなく, 食道神経 筋の変化, さらに食道に隣接する器官の異常,
第 19 図

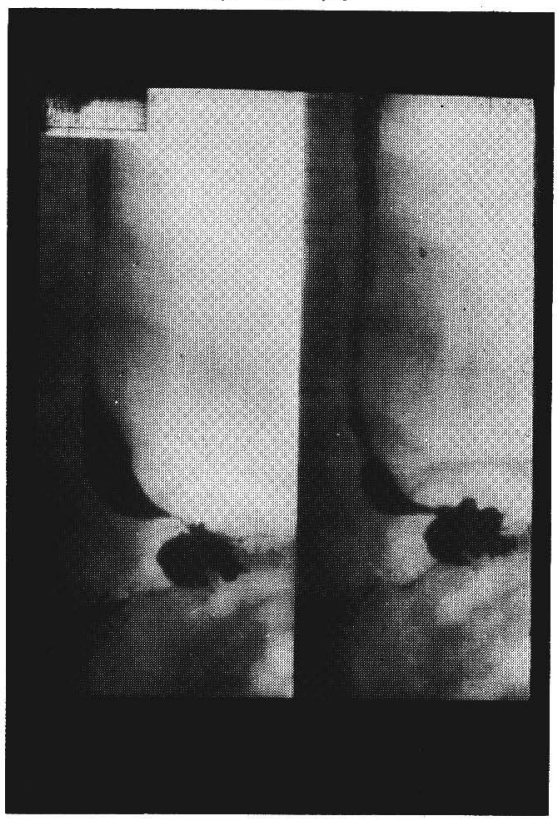

第 20 図

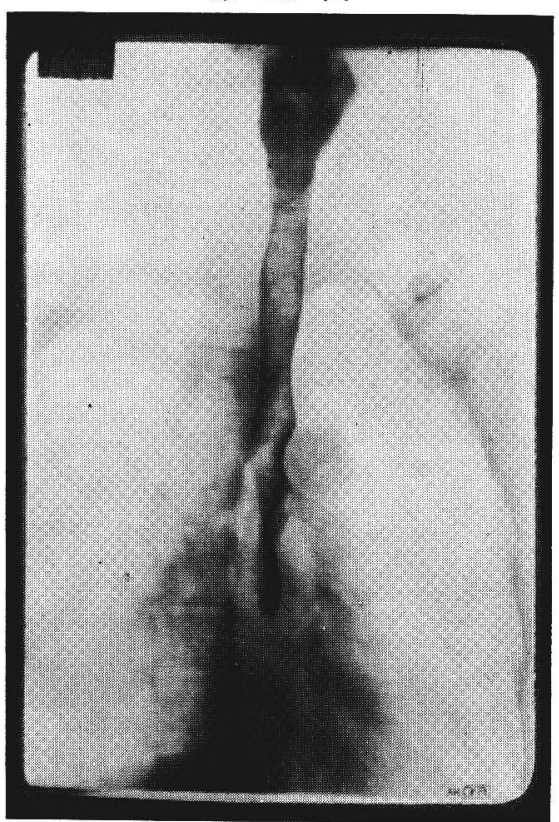

病変などによつて影響を受けているといらこと である。この観点からして胃切除後のものにお けて食道の動態を観察すると, hypotonia の状 が認められ， Relief で粘膜被譬の巾広いものが あり，横被が認められる。

即ち以上記して来たことからして食道病変は 
気食会報一 18 巻

食道の器質的病患, 機能的疾患のみでなく, 周 辺器官の異常による器質的変化, 機能的異常に よつても惹起される。ことが知られる。又その 食道病変は動態の観察によつてのみ, 始めてそ の全貌を知り得ることの少くないことを明かに した。従つて食道病変の診断のためには食道の 動的観察を行らことによつて従来よりは一層正 確にしかも病変を見逃すことがなくなつて来 た。しかしてその動的観察にはX線映画, X線 テレビ，連続撮影などが用いられるが，反復し て検討し得ることからすれば，X線映画及び連 続撮影が最もよい。今迄記して来た様に映画に よつては鮮明度が少しく悪いので, 連続撮影も 欠くことが出来ない。現在の段階においては映 画又はテレビと連続撮影とが望まれる食道動態
のX線による観察に必要なものである。

\section{おわりに}

食道病変をX線によつて動的に観察すると， 色々の因子がからんでいることが解り，その臨 床的意義簡単には割り切れない。そこに他の 観察方法, 検查方法を併用して診断的の価值が あることが多いのである。しかし他方X線テレ ビ，連続撮影が漸次普及しつつある時におい て，食道動態の観察は次第に容易になつて来 た。かくして食道疾患或いはその病態の判定に は食道動態の観察が次第に重要性を増して来 た。

本論文は昭和 41 年 9 月札璂における第 18 回日本気 管食道学会のシンポジウム「食道の動態と臨床」に お汸要旨を補経したものである。

\section{投稿規定}

1）投稿者は本学会々員であること。

2）原稿は新かなづかいで, 楷書, 横書, 簡潔明瞭なること。句読点を正確に, 外国語, 薬品名はカタカ ナを用い「」や——をつけいこと。

3）論文は組上り 3 頁まで（400字詰原稿用紙約15枚），但し特例を認めることがあります。規定頁数を超 える場合は超過分の実費並びに超過郵送料をいただきます。

4） 200 字以内の和文抄録（その英訳も一緒䎲）を必ずつけて下さい。但し英訳のない場合は英文抄録作 製料をいただきます。

5）文献は重要なるののみにして著者名, 題名, 雑誌名, 巻, 頁, 年号の順に統一して下さい。

6) 附図は白紙に墨ではつきり描いて下さい。色で描いたもの, 又は不鮮明なものは製版ができず描き直 すことになりますが，その場合は実費をいただきます。図版，写真版の製版は実費をいただきます。

7）別冊御希望の方は論文と同時御申込み下さい。但し実費をいただきます。

8）原稿は東京都新宿区信濃町35 慶応大学医学部内 日本気管食道科学会宛打送り下さい。揭載の採否は 編集員清まかせ下さい。 